\title{
Two new species of peacock spider of the Maratus mungaich species-group (Araneae: Salticidae) from south-western Australia
}

\author{
Julianne M. Waldock \\ Department of Terrestrial Zoology, Western Australian Museum, Locked Bag 49, Welshpool DC, \\ Western Australia 6986, Australia.
}

Email: julianne.waldock@museum.wa.gov.au

\begin{abstract}
Following the redefinition of the Banksia Peacock Spider, Maratus mungaich, and the recognition of four related species in the $M$. mungaich species-group, two more new species can be added to this group: Maratus hortorum sp. nov. was previously misidentified as $M$. mungaich Waldock, 1995 but it is here recognised as a distinct species; and M. madelineae sp. nov. has been found occurring in the gap created by the reduced distribution of $M$. mungaich and the five more southern species (M. karrie Waldock, 2013, M. melindae Waldock, 2013, M. sarahae Waldock 2013, M. caeruleus Waldock, 2013, and M. avibus Otto and Hill, 2014a). These new species are herewith described.
\end{abstract}

KEYWORDS: taxonomy, morphology, south-western Western Australia

\section{INTRODUCTION}

The jumping spider genus Maratus Karsch, 1878 is endemic to the Australian region, and currently includes 49 described species (Otto and Hill 2014d; World Spider Catalog 2014). The males of most species have brightly coloured abdomens which have lateral flaps that are inflated during courtship displays with females (Figures 10, 20). Males of many species also have enlarged, setose third legs which are used in the complex display performance (Figure 10). The $M$. mungaich species-group (see Waldock, 2013; Otto and Hill, 2014a) is one of the most distinctive assemblages within the genus, and is restricted to south-western Western Australia where five species are currently recognised. These include M. mungaich Waldock, 1995, M. karrie Waldock, 2013, M. melindae Waldock, 2013, M. sarahae Waldock, 2013, M. caeruleus Waldock, 2013 and M. avibus Otto and Hill, 2014a. Males of this group possess a colour pattern of alternate transverse red stripes on the dorsal abdominal surface (Waldock 2013; Otto and Hill 2014a).

Eight male specimens of Maratus collected from Talbot Road Reserve (now known as Talbot Road Regional Reserve) in the 1990s were previously identified as M. mungaich (Waldock 1995, 2013) but further recent collections from this site and reassessment of earlier collections have revealed additional specimens which confirm this as a unique species, described in this paper as M. hortorum sp. nov. In addition, recent collections near Dardanup have revealed a further undescribed species from the southwest forests mid-way between the known ranges of $M$. mungaich (which extends north to Toodyay, south to Mt Cooke, and east to Darkin Road) (Waldock 1995), and those of the southern species, M. karrie, M. melindae, M. sarahae, M. caeruleus and M. avibus (Waldock 2013; Otto and Hill 2014a).

\section{MATERIAL AND METHODS}

The material examined for this study is lodged in the Western Australian Museum, Perth, Australia (WAM). Specimens were preserved and described in $75 \%$ or $100 \%$ ethanol, illuminated with Halogen lights, and illustrated with the abdomen and cephalothorax in a flat, horizontal position. Female genitalia were examined by dissecting epigynes and clearing them in $10 \%$ lactic acid overnight. Epigynes were mounted in glycerol and illustrated with a camera lucida on a Leica DM 2500 compound microscope. Other drawings and measurements were made using a Leica MS5 or Leica MZ16A stereo microscope and Leica Application Suite V3.8.0 from Leica Microsystems Ltd. 


\section{TAXONOMY}

\section{Family Salticidae Blackwall, 1841}

Subfamily Euophryinae Simon, 1901

Genus Maratus Karsch, 1878

Maratus Karsch 1878: 27.

\section{TYPE SPECIES}

Maratus amabilis Karsch, 1878, by subsequent designation of Bonnet (1957: p. 2713).

\section{COMPOSITION}

Twenty-four described species - Maratus amabilis Karsch, 1878, M. avibus Otto and Hill, 2014a, M. caeruleus Waldock, 2013, M. calcitrans Otto and Hill, 2012c, M. clupeatus Otto and Hill, 2014c, M. digitatus Otto and Hill, 2012c, M. harrisi Otto and Hill, 2011, M. karrie Waldock, 2013, M. leo Otto and Hill, 2014d, M. linnaei Waldock, 2008, M. literatus Otto and Hill, 2014d, M. maritimus Otto and Hill, 2014d, M. melindae Waldock, 2013, M. montanus Otto and Hill, 2014d, M. mungaich Waldock, 1985, M. pardus Otto and Hill, 2014b, M. pavonis (Dunn, 1947), M. plumosus Otto and Hill, 2013, M. sarahae Waldock, 2013, M. speciosus (O.P.-Cambridge, 1874), M. rainbowi (Roewer, 1951), $M$. tasmanicus Otto and Hill, 2013, M. vespertilio (Simon, 1901), M. volans (O.P.-Cambridge, 1874), M. watagansi Otto and Hill, 2013 - and at least 15 undescribed species (Waldock, unpublished data). However, Otto and Hill (2012b) synonymised Lycidas Karsch, 1878 (type species L. anomalus Karsch, 1878) with Maratus, greatly expanding the limits of the latter genus and taking the total number of described species to 49 .

\section{REMARKS}

The specific (and often spectacular) colour patterns on male Maratus species are the result of specialised short squamous setae, which cover the dorsal abdominal scute and parts of the dorsal carapace (Figures 10, 20, 21, 22). These setae reflect different colours depending on the angle of orientation and also reflect different colour spectra on different parts of the abdomen (Figures 21, 22).

When preserved in alcohol, the vibrancy of the colours may be reduced, e.g. squamous setae that appear red in life will show as orangey to light brown over time. To standardise the colour pattern descriptions, the specimens were viewed under Halogen lights with the abdomen and cephalothorax in a flat, horizontal position. This combination leads to the squamous setae reflecting colours as rose-gold, orangey, brown and pink. When the abdomen is raised to a vertical position the rose-gold squamous setae reflect as electric blue; in life these rose-gold coloured areas are blue-green.

To simplify the descriptions the stripes that are red in life (i.e. orangey to light brown in ethanol) are stippled and termed as A, B and C (Figures 1, 11) and the anterior and posterior extensions from these main stripes are called 'arms' (see Figure 22).

\section{Maratus madelineae sp. nov.}

Madeline's Peacock Spider

Figures $1-10$

http://www.zoobank.org/urn:Isid:zoobank. org:act:0677326E-A36D-4E45-A6C3-56525CC7E9DF

\section{MATERIAL EXAMINED}

\section{Holotype}

Australia: Western Australia: , Dardanup National Park, 3325'04.2”S, 11548'36.9”'E, 26 September 2013, M.B. Girard, D.O. Elias, J.M. Waldock (WAM T130294).

\section{Paratypes}

Australia: Western Australia: 3 , same data as holotype (WAM T131966-8); 2 , same data as holotype (WAM T132135-6).

\section{DIAGNOSIS}

Males of Maratus madelineae can be distinguished from all other species in the M. mungaich species-group by the presence of a broad rather than a narrow stripe C dorsally; by the small, circular central black patch almost encircled by red; and by the discontinuous dorsal abdominal stripes A, B and C, with stripe B fragmented and with branches linking to stripe A. This species can be further distinguished by the presence of a glossy blue-black patch on each abdominal flap (Figures 3, 10), and by the setation of leg III, with black brushes on all segments and distinctive white bristles in clumps on the femur, patella and tibia (Figures 4, 10).

\section{DESCRIPTION}

\section{Male (holotype)}

Cephalothorax black to dark brown with white hairs bordering lateral edges. Dense mat of light orange squamous setae covering ocular region; oval patch of white hairs posterior to fovea. Anterior eyes fringed with creamy hairs along dorsal margin; rest of cephalothorax lightly covered with scattered short white hairs and brown bristles (Figure 1). Clypeus yellowy-brown, chelicerae dark brown, cream distally. Maxillae light cream, labium dark grey with cream edge. Sternum dark grey.

Venter of abdomen dark yellow with greyish smudges in centre and laterally; spinnerets black. Dorsal abdominal scute developed as lateral flaps which fold over each other ventrally, but extendable laterally to exhibit a continuation of dorsal pattern (Figures 3,10). Stripe A of red-orange squamous setae present, extending as broad band from the flaps but not continuous across dorsum. Stripe B of red-orange also broad extending posteriorly on sides of abdomen, on dorsum disjointed, not reaching central black patch. Circular central black patch with a 

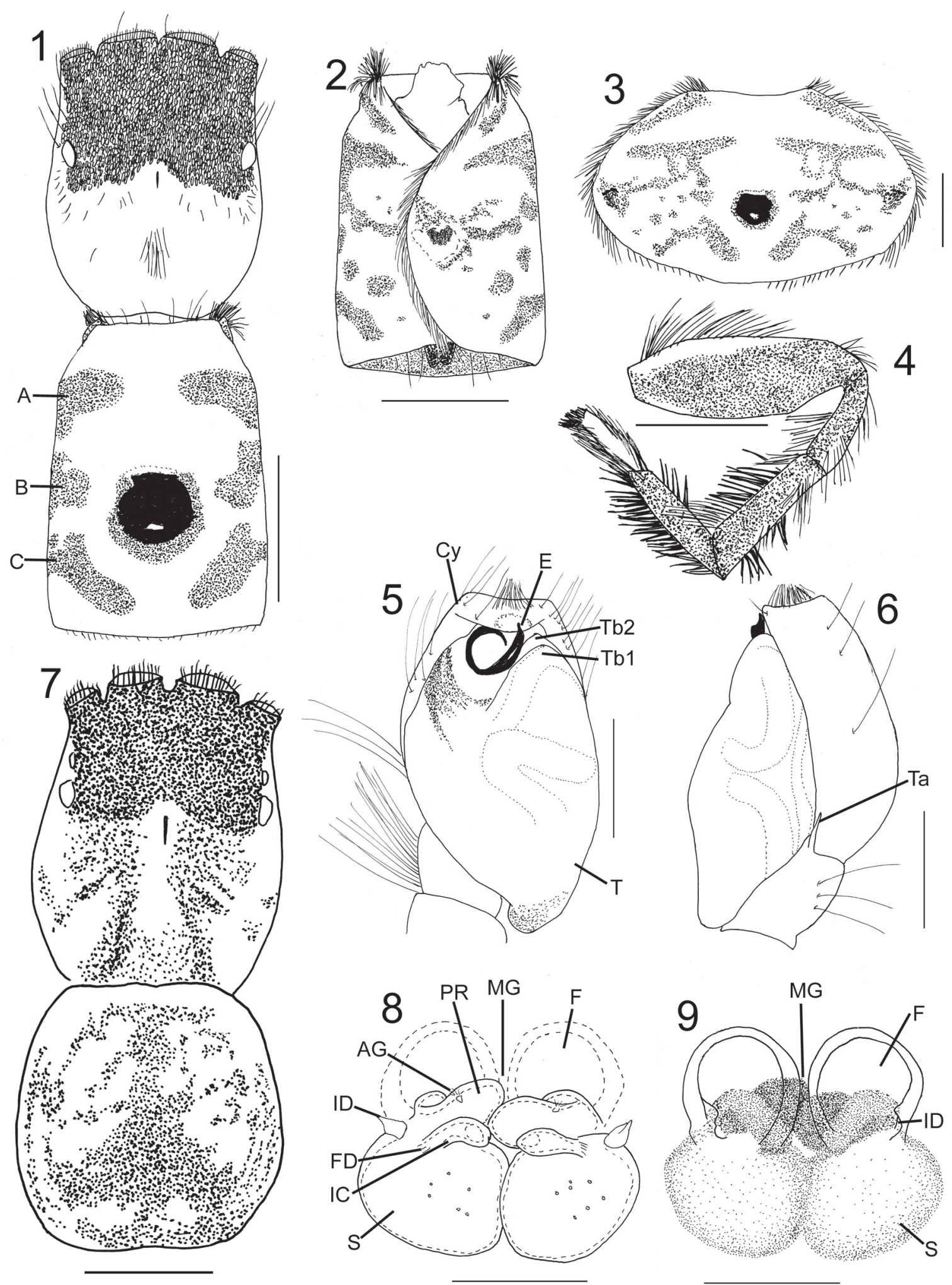

FIGURES 1-9 Maratus madelineae sp. nov., male holotype (WAM T130294): 1, cephalothorax and abdomen, dorsal view; 2, abdomen, ventral view (abdominal flaps folded); 3, abdomen extended from image in Figure 10; 4, left leg III, prolateral view; 5, left pedipalp, ventral view; 6, left pedipalp, retrolateral view. Female paratype (WAM T132135): 7, cephalothorax and abdomen, dorsal view; 8, cleared epigyne (WAM T132136), dorsal view; 9, epigyne (WAM T132136), ventral view. Scale lines $=1 \mathrm{~mm}$ (Figures 1, 2, 3, 4, 7), $0.5 \mathrm{~mm}$ (Figures 5, 6), $0.25 \mathrm{~mm}$ (Figures 8, 9). A, B, C = red transverse stripes $\mathrm{A}-\mathrm{C} ; \mathrm{AG}=$ accessory gland; $\mathrm{Cy}=$ cymbium; $\mathrm{E}=$ embolus; $\mathrm{T}=$ tegulum; $\mathrm{TA}=$ tibial apophysis; TB1-2 = tegular bulges 1-2; $A G=$ accessory gland; $F=$ fossa; $F D=$ fertilisation duct; $I C=$ intermediate canal; ID = insemination duct; $M G=$ median guide; $P R=$ proximal receiver; $S=$ spermatheca. 


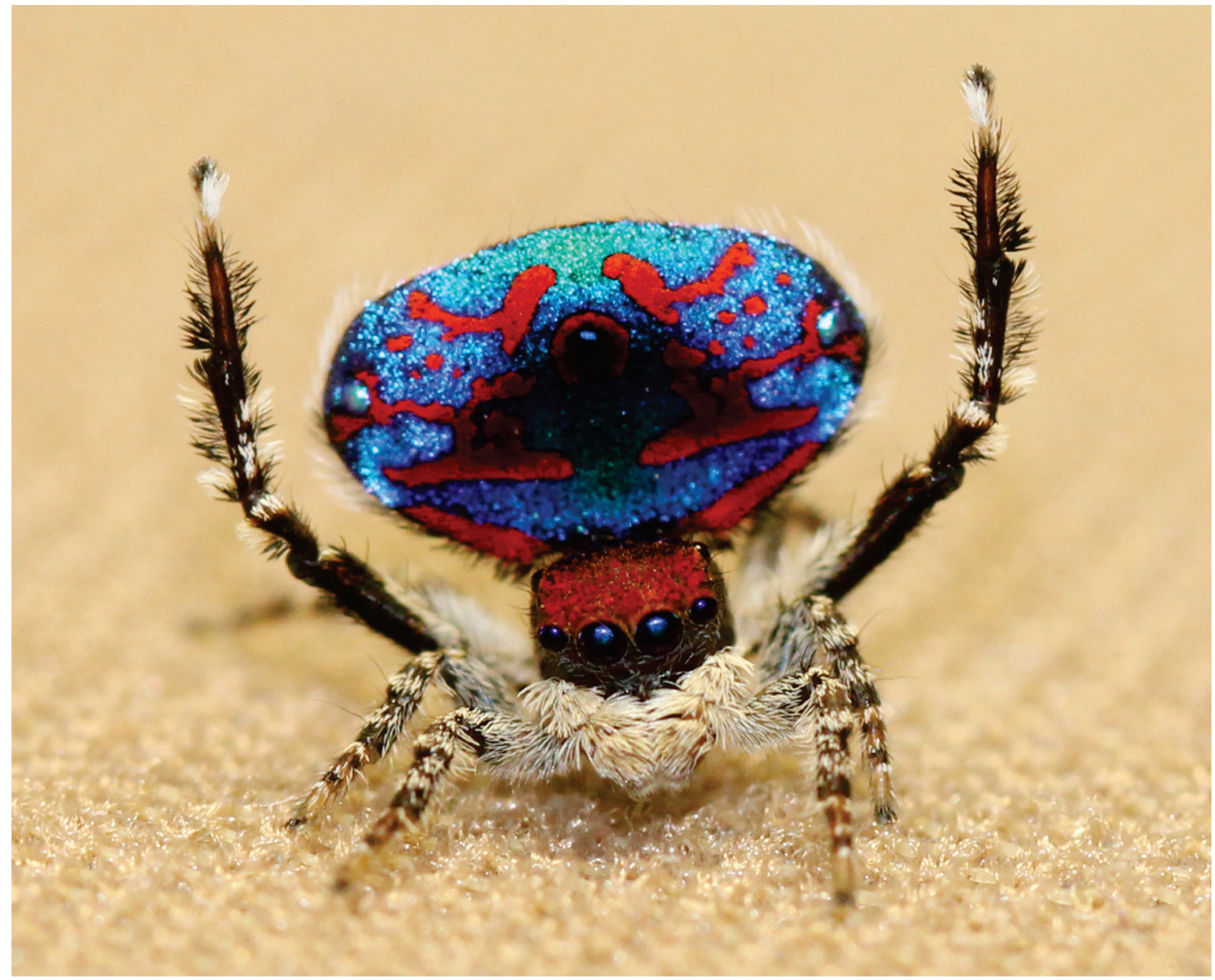

FIGURE 10

Maratus madelineae sp. nov., male from Dardanup National Park, Western Australia, 26 September 2013 with expanded abdominal flaps, displaying for female. (Image courtesy Madeline Girard.)

very narrow light blue strip anteriorly and with small light blue spot off-centre to posterior, band of red-orange surrounds black patch except along anterior edge where light blue strip occurs (Figures 1, 10). Stripe C dissected into red-orange patches of squamous setae laterally, directed posteriorly below central black patch extending onto flaps (Figures 1, 10). Anterior corners of abdomen with stiff orange and black bristles. Stiff long cream and brown bristles projecting from anterior border of abdomen (Figure 1). Lateral flaps with blue-black circular 'eye' patch anteriorly near edge of flap; 'eye' patch almost entirely encircled with red-orange anteriorly (stripe B), remainder of flaps rose-gold and bright blue. Stripes A, $\mathrm{B}$ and $\mathrm{C}$ extend from dorsum onto flaps; stripe $\mathrm{B}$ reaches edge of flap; anterior edge of flap with broad red-orange elongate strip (Figures 3, 10). Long black or dark brown hairs bordering anterior edge of flaps, long creamy hairs laterally (Figures 2, 3).

Legs I, II and IV: proximal femora cream dorsoanteriorly with dark grey patches ventro-posteriorly; patellae, tibiae, metatarsi and tarsi yellow with grey bands at joints; covered with dense short white hairs interspersed with black bristles. Leg III: proximal dorsal femur cream, rest dark grey dorsally and ventrally, patella and tibia dark grey except for light orange dorsal stripe, metatarsus grey, tarsus cream. Patella and tibia III with thick brush hairs dorso-ventrally, brush hairs in bunches of black and white (Figure 10); metatarsus III with thick brush of dark grey hairs, dorso-ventrally; tarsus III with thick short white hairs on all surfaces and longer white hairs at tip, covering claws (Figures 4, 10).

Pedipalp creamy yellow with scattered greyish patches distally. Tibial apophysis narrow, straight (Figure 6). Cymbium, dorsal tibia and dorsal patella densely covered with long white hairs, a single very long black hair on dorsal pedipalpal patella; tibia and cymbium with a few long creamy and brown hairs on ventral side just under tegulum. Embolus with conductor closely aligned into tight coil, tucked under tip of cymbium; tegulum with two bulges adjacent to embolus (Figure 5). 


\section{Female (paratype, WAM T132136)}

Ocular region black, densely covered with short black and creamy hairs, rest of cephalothorax yellowishgrey grading to light yellow towards posterior with scattered black hairs. Posterior to ocular area and fovea, dark grey; two broad grey bands extend to posterior margin with light yellow central strip (Figure 7). Sides of cephalothorax greyish-yellow. Clypeus light yellow; chelicerae, maxillae, labium light yellow with white border. Sternum cream with light grey edging.

Abdomen oval with tan dorsal sigillae and black bristles scattered amongst brown and creamy hairs; most of dorsum covered in greyish diffuse pattern on creamy background; pattern darkens and narrows to point above spinnerets (Figure 7). Venter of abdomen cream, with small grey spots in longitudinal rows, larger spots at edges. Ventral spinnerets light grey, dorsal pair dark grey.

Femora and patellae of legs creamy, no markings dorsally, grey patches at joints and mid-way of femora; tibiae, metatarsi and tarsi yellowy with grey bands at joints.

Proximal receivers of epigyne large and abutting each other at median guide. Intermediate canals resting on spermathecae, openings directed off-centre of anterior of spermathecae. Insemination ducts opening centrally above anterior portion of spermathecae (Figures 8,9 ).

\section{Dimensions (mm)}

Holotype (paratype , WAM T132136): total length excluding chelicerae 6.98 (8.86). Carapace length 3.30 (3.75). Abdomen length 3.68 (4.52). Leg I: femur 1.52 (1.50), patella 0.94 (0.92), tibia $0.74(0.78)$, metatarsus 0.72 (0.61), tarsus 0.55 (0.62). Leg II: femur 1.31 (1.68), patella 1.14 (1.16), tibia $0.72(0.76)$, metatarsus 0.74 (0.55), tarsus 0.54 (0.56). Leg III: femur 2.72 (2.47), patella $0.88(0.96)$, tibia 1.45 (1.48), metatarsus 1.12 (1.18), tarsus 0.74 (0.76). Leg IV: femur 1.90 (1.79), patella $0.86(1.08)$, tibia $1.06(1.25)$, metatarsus 1.47 (1.11), tarsus 0.63 (0.86). Legs, relative lengths: III: IV: I: II (III: IV: II: I).

\section{VARIATION}

The additional males and females differ little from the holotype male and paratype female described above.

\section{DISTRIBUTION}

Maratus madelineae has only been recorded from Dardanup National Park in Banksia, jarrah (Eucalyptus marginata) and marri (Corymbia calophylla) woodland.

\section{ETYMOLOGY}

The specific epithet is a patronym in honor of Madeline Girard, enthusiastic researcher uncovering the wonders of the complex behaviours of these fascinating spiders.

\section{Maratus hortorum sp. nov.}

Hort's Peacock Spider

Figures 11-22

http://www.zoobank.org/urn:Isid:zoobank. org:act:D83CC4D6-4311-41D8-B296-5EF0436222AF

Maratus mungaich Waldock, 1995: 167 (in part, misidentification of specimens from Talbot Road Reserve); Otto and Hill, 2012a: 1, figure 7(4); Otto and Hill, 2014a: 13, figure 17(2) (references to specimens from Talbot Road Nature [sic.] Reserve).

\section{MATERIAL EXAMINED}

\section{Holotype}

Australia: Western Australia:, Stratton, Talbot Road Regional Reserve, 31'52’22.8”S, 116 02'39.8”'E, 13 August 2014, open Banksia woodland, F. Hort, J. Hort (WAM T133826).

\section{Paratypes}

Australia: Western Australia: 1, same data as holotype (WAM T133827); 1 , Talbot Road Reserve, site 1, 31 ${ }^{\circ} 52^{\prime} 05^{\prime \prime S}, 116^{\circ} 03^{\prime} 04^{\prime \prime E}, 28$ July 1993, J.M. Waldock, A. Sampey (WAM 93/1650); 1 , 1 juvenile, Talbot Road Reserve, site 1, wet pitfalls, 31 ${ }^{\circ} 52^{\prime} 05^{\prime \prime} \mathrm{S}$, $116^{\circ} 03^{\prime} 04^{\prime \prime E}, 10$ May-24 June 1993, M.S. Harvey, J.M. Waldock (WAM 93/2336-7); 3 , 1 juvenile, Talbot Road Reserve, site 1 , wet pitfalls, $31^{\circ} 52^{\prime} 05^{\prime \prime} \mathrm{S}, 116^{\circ} 03^{\prime} 04^{\prime \prime} \mathrm{E}$, 24 June-28 July 1993, M.S. Harvey, J.M. Waldock, A. Sampey (WAM 93/2338-41); 3 , 1 , Talbot Road Reserve, site 4, wet pitfalls, $31^{\circ} 52^{\prime} 23^{\prime \prime S}, 116^{\circ} 02^{\prime} 46^{\prime \prime} \mathrm{E}$, 24 June-28 July 1993, M.S. Harvey, J.M. Waldock, A. Sampey (WAM 93/2342-5).

\section{DIAGNOSIS}

Males of Maratus hortorum can be distinguished from all other species in the M. mungaich species-group by the presence of two light blue patches within a central, rectangular patch on the dorsal abdomen (Figures 11, 20-22); by the presence of a very small, central black patch almost encircled by red on each abdominal flap; and by the continuous dorsal abdominal stripes A and C, with stripe $\mathrm{B}$ extending to central black patch and with branches bordering black patch. This species can further be distinguished by the presence of an electric blue and black patch on each abdominal flap (Figures 13, 20), and by the setation of leg III, with black brushes ventrally on all segments except the tibia and tarsus (Figure 14), and tarsus III with a white brush of long hairs dorsally. Females of M. hortorum differ from M. mungaich by the foreshortened proximal receivers that do not meet across the median guide (Figures 18, 19) and by the presence of a solid dark patch on the dorsal surface of the abdomen (Figure 15). 

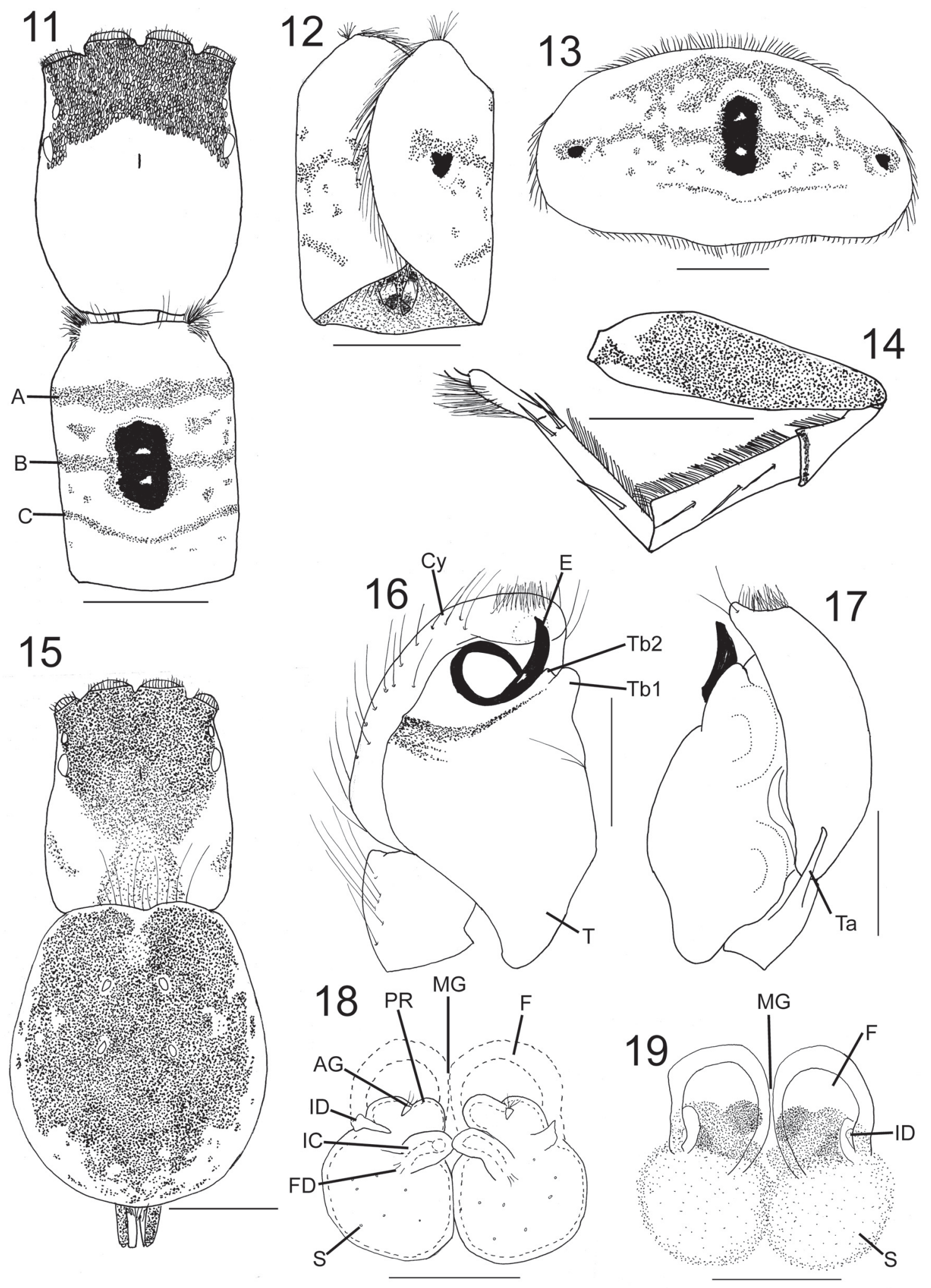

FIGURES 11-19 Maratus hortorum sp. nov., male holotype (WAM T133826): 11, cephalothorax and abdomen, dorsal view; 12, abdomen, ventral view (abdominal flaps folded); 13, abdomen extended (WAM 93/2342); 14, left leg III, prolateral view; 16, left pedipalp, ventral view; 17, left pedipalp, retrolateral view. Female paratype (WAM T133827): 15, cephalothorax and abdomen, dorsal view; 18, cleared epigyne, dorsal view; 19, epigyne, ventral view. Scale lines $=1 \mathrm{~mm}$ (Figures 11, 12, 13, 14, 15), $0.5 \mathrm{~mm}$ (Figures 16, 17), $0.25 \mathrm{~mm}$ (Figures 18, 19). $A, B, C=$ red transverse stripes $A-C ; A G=$ accessory gland; $C y=$ cymbium;

$\mathrm{E}=$ embolus; $\mathrm{T}=$ tegulum; $\mathrm{TA}=$ tibial apophysis; $\mathrm{TB} 1-2=$ tegular bulges $1-2 ; \mathrm{AG}=$ accessory gland; $F=$ fossa; FD = fertilisation duct; $I C=$ intermediate canal; ID = insemination duct; $M G$ = median guide; $\mathrm{PR}=$ proximal receiver; $\mathrm{S}=$ spermatheca. 


\section{DESCRIPTION}

\section{Male (holotype)}

Cephalothorax black to dark brown with white hairs bordering lateral edges. Dense mat of light orange squamous setae covering ocular region; no white hairs evident in patch posterior to fovea. Anterior eyes fringed with orangey hairs along dorsal margin; rest of cephalothorax lightly covered with scattered short white hairs and dark brown bristles (Figure 11). Clypeus yellowy-brown, chelicerae dark brown, cream distally. Maxillae light cream, labium dark grey with cream edge. Sternum dark grey.

Venter of abdomen dark yellow with greyish smudges in centre and laterally; distal tips of spinnerets black, rest cream (Figure 12). Dorsal abdominal scute developed as lateral flaps which fold over each other ventrally, but extendable laterally to exhibit a continuation of dorsal pattern (Figures 13, 20). Stripe A of red-orange squamous setae present as a broad, continuous band across dorsum, not extending onto lateral flaps (Figures 11, 12, 13, 20). Stripe B of redorange, narrower than stripe A, reaching central black patch, with arms extending anteriorly and posteriorly to almost surround central black patch. Stripe B continues onto lateral flaps almost to edge bordering electric blue/ black 'eye' near middle of lateral flap (Figures 11, 12, 13, 20). Rectangular central black patch with a very narrow light blue strip anteriorly and with two small light blue spots in centre to anterior and posterior (Figures 11, 13, 20). Stripe $\mathrm{C}$ narrow, continuous across dorsum, extending almost to edges of lateral flaps (Figures 11,

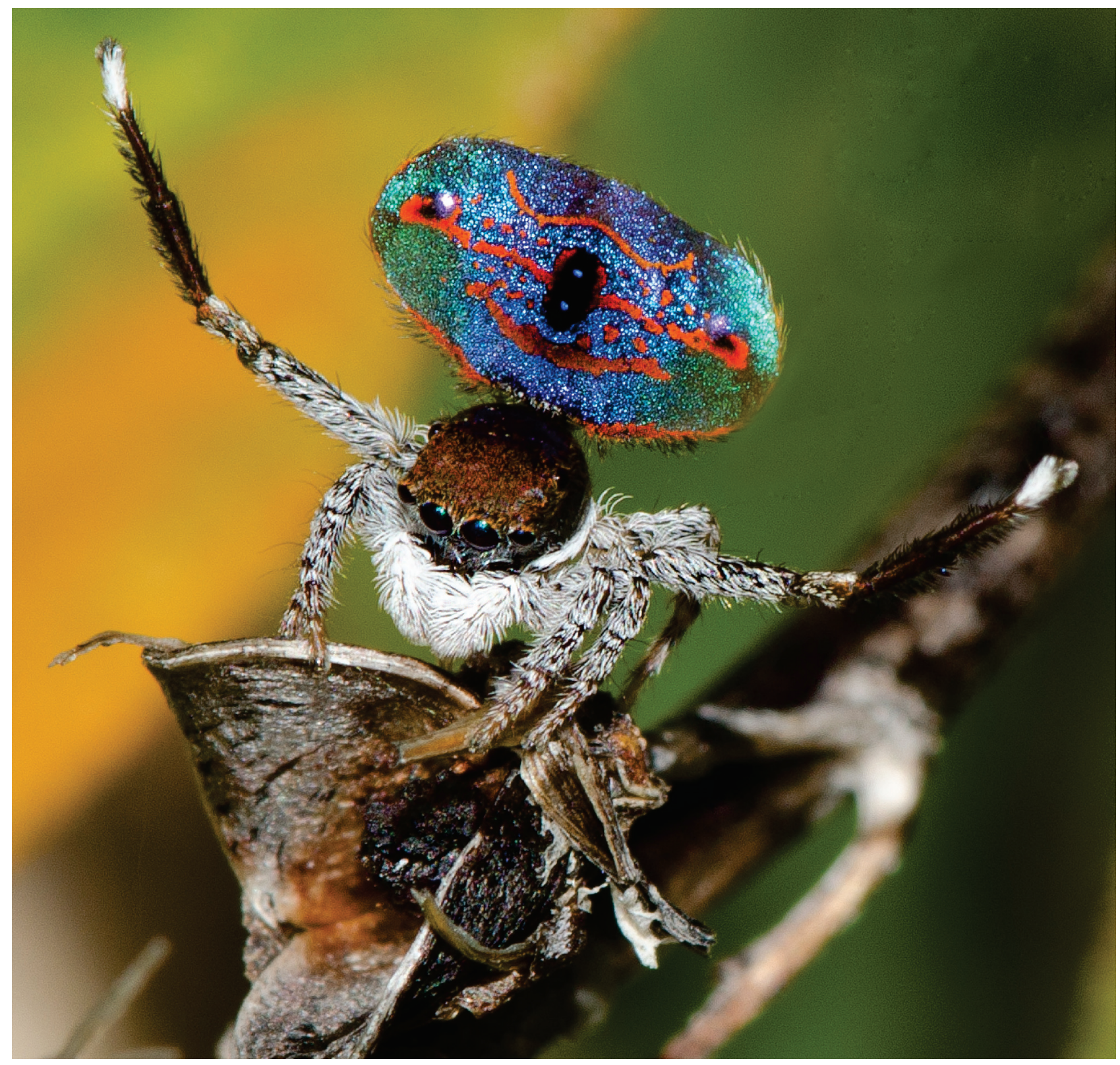
with expanded abdominal flaps, displaying for female. (Image courtesy F. Hort, J. Hort.) 
12, 13, 20). A large red-orange patch on dorsum between stripes A and B on either side of central black patch (see note below on variation) (Figures 11, 21). Two small red-orange patches on dorsum between stripes $\mathrm{B}$ and $\mathrm{C}$ on either side of central black patch. Anterior corners of abdomen with stiff orange and black bristles. Stiff long cream and brown bristles projecting from anterior border of abdomen (Figures 11, 21). Lateral flaps with electric blue circular 'eye' patch anteriorly near edge of flap; 'eye' patch almost entirely encircled with redorange anteriorly (stripe B), remainder of flaps rosegold and bright blue (Figures 12, 13, 21). Long black or dark brown hairs bordering anterior edge of flaps, long creamy hairs laterally (Figures 12, 13).

Legs I, II and IV: proximal half of femora cream dorso-anteriorly and rest dark grey with dark grey patches ventro-posteriorly; tibiae orange and patellae and metatarsi yellow with grey bands at joints; tarsi cream, covered with dense short white hairs interspersed with black bristles. Leg III: proximal quarter of dorsal femur cream, rest dark grey dorsally and ventrally, patella, orange; tibia dark brown; metatarsus orange, tarsus cream. Patella III with thick black brush ventrally, tibia and metatarsus III with thick black brush hairs dorso-ventrally (Figures 14, 20); tarsus III with thick short white hairs on all surfaces and longer white hairs at tip, covering claws (Figure 14).

Pedipalp creamy yellow with scattered greyish patches distally. Tibial apophysis narrow, straight (Figure 17). Cymbium, dorsal tibia and dorsal patella densely covered with long white hairs, a single very long black hair on dorsal pedipalpal patella, tibia and cymbium with a few long creamy and brown hairs on ventral side just under tegulum. Embolus with conductor closely aligned into tight coil, tucked under tip of cymbium; tegulum with two bulges adjacent to embolus (Figure 16).

\section{Female (paratype, WAM T133827)}

Ocular region black, densely covered with short black and creamy hairs, rest of cephalothorax with light grey patches grading to greyish-yellow laterally, a broad grey strip extends from posterior of fovea to posterior edge, lightening under a central patch of white hairs (Figure 15). Ocular area with dense cover of short cream and light brown hairs which become longer and more

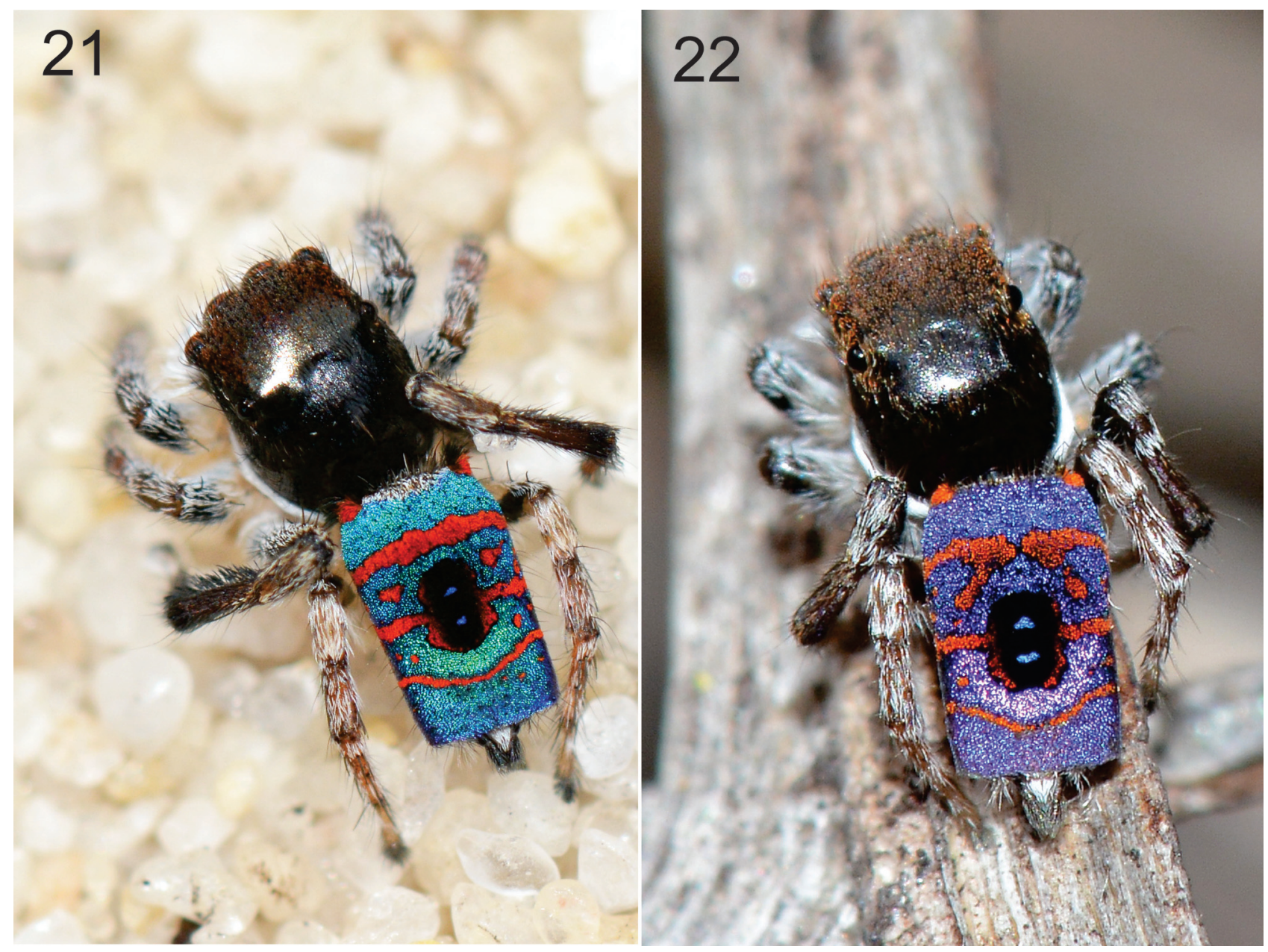

FIGURES 21-22 Maratus hortorum sp. nov., males from Talbot Road Regional Reserve, Western Australia: 21, 13 August 2013; 22, 16 August 2012. Note the variation in the colour patter on the anterior abdomen.

(Images courtesy F. Hort, J. Hort.) 
dispersed laterally and posteriorly. Clypeus cream; chelicerae yellow with light grey patches, maxillae, labium light yellow with white border. Sternum cream with light grey edging.

Abdomen oval with tan dorsal sigillae and black bristles scattered amongst brown and creamy hairs; most of dorsum covered in dark grey to black patch on light cream background; patch extends to spinnerets (Figure 15), edges of dorsum light cream with scattered dark grey to black patches. Venter of abdomen light cream, with larger dark grey stripes at edges. Dorsal spinnerets dark grey to black, ventral pair pale yellow.

Femora light cream with light grey patches distally, more-so for legs III and IV; patellae of legs creamy, no markings; tibiae, metatarsi and tarsi yellowy, tibiae III and IV with grey bands at joints, rest of leg segments without banding.

Proximal receivers of epigyne short, not meeting across median guide. Intermediate canals shortened, meeting across median guide, angled towards centre of anterior of spermathecae. Insemination ducts opening laterally over spermathecae (Figures 18, 19).

\section{Dimensions ( $\mathrm{mm})$}

Holotype (paratype , WAM T133827): total length excluding chelicerae 4.50 (5.45). Carapace length 2.17 (2.18). Abdomen length 2.24 (2.89). Leg I: femur 0.84 (0.83), patella $0.60(0.57)$, tibia $0.69(0.61)$, metatarsus 0.49 (0.43), tarsus $0.42(0.43)$. Leg II: femur $0.84(0.99)$, patella $0.42(0.69)$, tibia $0.52(0.47)$, metatarsus 0.32 (0.34), tarsus 0.28 (0.42). Leg III: femur 1.84 (1.62), patella $0.57(0.75)$, tibia $1.10(0.91)$, metatarsus 0.98 (0.54), tarsus 0.52 (0.47). Leg IV: femur 1.27 (1.23), patella $0.41(0.67)$, tibia $0.60(0.70)$, metatarsus 0.93 (0.83), tarsus $0.53(0.50)$. Legs, relative lengths: III: IV: II: I (III: IV: II: I).

\section{VARIATION}

The colour pattern of males of $M$. hortorum is variable with two broad forms that co-occur: a form with two large red-orange patches on the abdominal dorsum between stripes A and B, either side of the central black patch (see holotype description and Figures 11, 21); and a second form with posteriorly-directed branches extending diagonally from stripe A on either side of the central black patch (Figure 22).

\section{DISTRIBUTION}

Maratus hortorum has only been recorded from Talbot Road Regional Reserve in the northern metropolitan region of Perth, at the base of the Darling Range.

\section{REMARKS}

Adults of Maratus hortorum have been recorded as being active earlier than $M$. mungaich, the latter of which occurs in nearby forests on the Darling Range. Jean and Fred Hort have observed M. hortorum as early as June, with pitfall trapped specimens overlapping with M. mungaich in mid-winter, June to July.

\section{ETYMOLOGY}

The specific epithet is in honour of Jean and Fred Hort, tireless photographic recorders of the natural history at their doorstep.

\section{ACKNOWLEDGEMENTS}

I would like to acknowledge the generosity of Madeline Girard for inviting me to accompany her with Prof. Damian Elias on her collecting expedition to southwestern Australia as part of her graduate project on the evolution of elaborate male displays and female preference in the peacock spider (Maratus volans) at The University of California, Berkley, U.S.A. and The University of New South Wales, Sydney, Australia. Many thanks to Drs Mark Harvey and Michael Rix for their comments on an earlier draft of this paper.

\section{REFERENCES}

Blackwall, J. (1841). The difference in the number of eyes with which spiders are provided proposed as the basis of their distribution into tribes; with descriptions of newly discovered species and the characters of a new family and three new genera of spiders. Transactions of the Linnean Society of London 18: 601-670.

Bonnet, P. (1957). Bibliographia Araneorum, vol. 2(3). Douladoure: Toulouse.

Cambridge, O.P.- (1874). On some new genera and species of Araneida. Annals and Magazine of Natural History (4) 14: 178-183, plate 17.

Dunn, R. A. (1957). The peacock spider. Walkabout April 1957: 38-39.

Hort, J. (2012). https://www.flickr.com/photos/jean hort/7356879882/in/photostream/, accessed 27 October 2014.

Hort, F. (2013). Pleasure or pain? Western Wildlife 17 (3): 3.

Karsch, F. (1878). Diagnoses Attoidarum aliquot novarum Novae Hollandiae collectionis Musei zoologici Berolinensis. Mitteilungen des Münchener Entomologischen Verein, München 2: 22-32.

Otto, J.C. and Hill, D.E. (2011). An illustrated review of the known peacock spiders of the genus Maratus from Australia, with description of a new species (Araneae: Salticidae: Euophryinae). Peckhamia 96(1): 1-27.

Otto, J.C. and Hill, D.E. (2012a). Description of Darlington's Peacock Spider (Araneae: Salticidae: Euophryinae: Maratus species A) from the Stirling Range National Park of Western Australia. Peckhamia 101(1): 1-21.

Otto, J.C. and Hill, D.E. (2012b). Notes on Maratus Karsch 1878 and related jumping spiders from Australia, with five new species (Araneae: Salticidae: Euophryinae). Peckhamia 103(1): 1-81.

Otto, J.C. and Hill, D.E. (2012c). Two new Australian peacock spiders that display inflated and extended spinnerets (Araneae: Salticidae: Euophryinae: Maratus Karsh 1878). Peckhamia 104(1): 1-28.

Otto, J.C. and Hill, D.E. (2013). Three new Australian peacock spiders (Araneae: Salticidae: Maratus). Peckhamia 108(1): $1-39$. 
Otto, J.C. and Hill, D.E. (2014a). Spiders of the mungaich group from Western Australia (Araneae: Salticidae: Euophryinae: Maratus), with one new species from Cape Arid. Peckhamia 112(1): 1-35.

Otto, J.C. and Hill, D.E. (2014b). Description of a new peacock spider from Cape Le Grand, Western Australia, with observations on display by males and females and comparative notes on the related Maratus volans (Araneae: Salticidae: Euophryinae: Maratus). Peckhamia 114(1): 1-38.

Otto, J.C. and Hill, D.E. (2014c). Description of a new peacock spider from Gnangara Mound north of Perth, Western Australia (Araneae: Salticidae: Euophryinae: Maratus). Peckhamia 115(1): 1-8.

Otto, J.C. and Hill, D.E. (2014d). Peacock spiders of the pavonis group from southern Australia (Araneae: Salticidae: Euophryinae: Maratus). Peckhamia 117(1): 1-62.

Simon, E. (1901). Histoire Naturelle des Araignées, vol. 2: 381-668. Encyclopédie Roret: Paris.
Waldock, J.M. (1995). A new species of Maratus from southwestern Australia (Araneae: Salticidae). Records of the Western Australian Museum Supplement 52: 165-169.

Waldock, J.M. (2008). A new species of Maratus (Araneae: Salticidae) from southwestern Australia. Records of the Western Australian Museum 24: 369-373.

Waldock, J.M. (2013). A review of the peacock spiders of the Maratus mungaich species-group (Araneae: Salticidae), with descriptions of four new species. Records of the Western Australian Museum 28: 66-81.

World Spider Catalog (2014). World Spider Catalog. Natural History Museum Bern, online at http://wsc.nmbe.ch, version 15.5, accessed on 27 Oct. 2014.

Żabka, M. (1987). Salticidae (Araneae) of Oriental, Australian and Pacific Regions, II. Genera Lycidas and Maratus. Annales Zoologici 40: 451-482.

MANUSCRIPT RECEIVED 29 OCTOBER 2014; ACCEPTED 4 DECEMBER 2014. 